\title{
Comparative genomic hybridization and amplotyping by arbitrarily primed PCR in stage A B-CLL
}

\author{
Maria D. Odero ${ }^{\mathrm{a}, *}$ Jose L. Soto $^{\mathrm{b}}$, Estella Matutes ${ }^{\mathrm{c}}$, Jose I. Martin-Subero ${ }^{\mathrm{a}}$, Isabel Zudaire ${ }^{\mathrm{a}}$, \\ Pulivarthi H. Rao ${ }^{\mathrm{d}}$, Juan C. Cigudosa ${ }^{\mathrm{e}}$, Maria T. Ardanaz ${ }^{\mathrm{f}}$, R.S.K. Chaganti ${ }^{\mathrm{d}}$, \\ Manuel Perucho ${ }^{\mathrm{b}}$, Maria J. Calasanz ${ }^{\mathrm{a}}$ \\ ${ }^{a}$ Department of Genetics, University of Navarra, C/ Irunlarrea s/n, 31008-Pamplona, Spain \\ ${ }^{\mathrm{b}}$ The Burnham Institute, La Jolla Cancer Research Center, La Jolla, CA, USA \\ 'Department of Hematology, The Royal Marsden Hospital, London, UK \\ ${ }^{\mathrm{d}}$ Department of Medicine, Memorial Sloan-Kettering Cancer Center, New York, NY, USA \\ ${ }^{\mathrm{e}}$ Centro Nacional de Investigaciones Oncológicas, Madrid, Spain \\ ${ }^{\mathrm{f}}$ Department of Hematology, Hospital Txagorritxu, Vitoria, Spain \\ Received 16 February 2001; accepted 6 March 2001
}

\begin{abstract}
Cytogenetic analysis is useful in the diagnosis and to assess prognosis of B-cell chronic lymphocytic leukemia (B-CLL). However, successful cytogenetics by standard techniques has been hindered by the low in vitro mitotic activity of the malignant B-cell population. Fluorescence in situ hybridization (FISH) has become a useful tool, but it does not provide an overall view of the aberrations. To overcome this hurdle, two DNA-based techniques have been tested in the present study: comparative genomic hybridization (CGH) and amplotyping by arbitrarily primed PCR (AP-PCR). Comparative genomic hybridization resolution depends upon the 400-bands of the human standard karyotype. AP-PCR allows detection of allelic losses and gains in tumor cells by PCR fingerprinting, thus its resolution is at the molecular level. Both techniques were performed in 23 patients with stage A B-CLL at diagnosis. The results were compared with FISH. The sensitivity of AP-PCR was greater than CGH (62\% vs 43\%). The use of CGH combined with AP-PCR allowed to detect genetic abnormalities in 79\% (15/19) of patients in whom G-banding was not informative, providing a global view of the aberrations in a sole experiment. This study shows that combining these two methods with FISH, makes possible a more precise genetic characterization of patients with B-CLL. (C) 2001 Elsevier Science Inc. All rights reserved.
\end{abstract}

\section{Introduction}

The pathogenic events in chronic B-cell lymphocytic leukemia (B-CLL), the most common form of adult leukemia in Western countries, remains poorly understood. B-CLL is a malignancy of self-reactive, activated CD5+ B cells devoted to the production of polyreactive natural autoantibodies [1]. The clinical course of this disease is extremely variable; some patients survive only a few months whereas others have stable disease greater than 10 years [2]. Rai and Binet clinical staging systems are useful prognostic tools. However, they do not distinguish which patients in early stages of the disease will progress. Other prognostic parameters, e.g., short lymphocyte doubling time and/or dif-

* Corresponding author. Tel.: +34-948-425600; fax: 34-948-425649.

E-mail address: modero@unav.es (M.D. Odero). fuse bone marrow infiltration are known risk factors for progressive disease in early-stage CLL [2,3]. Although patients lacking these features have a low risk for disease progression, $10-15 \%$ of such cases will still progress within 5 years of diagnosis, emphasizing the need for additional prognostic factors in early CLL $[3,4]$.

Genetic studies have provided useful information in understanding the pathogenesis of CLL, and some aberrations may also have a prognostic impact [4-10]. In CLL, accurate and successful cytogenetic analysis has been hindered by the low in vitro mitotic activity of the critical B-cell population with metaphases arising from normal T-cells being frequent. Thus, G-banding analysis is informative in only a minority of cases. Although FISH has become a useful tool and, in some studies, showing to be informative in up to $80 \%$ of cases [10], it does not provide a global view of the chromosomal aberrations. Two molecular techniques 
that are not cell-growth based, comparative genomic hybridization $(\mathrm{CGH})$ and amplotyping by arbitrarily primed PCR (AP-PCR), have been recently introduced and applied to study genetic abnormalities in human malignancies. $\mathrm{CGH}$ allows tumor genomes to be tested for the presence of chromosomal unbalances without the need of metaphases and only requires small numbers of tumor cells to prepare DNA [11]. The resolution of this technique depends upon the 400bands of the human standard karyotype. AP-PCR is a molecular karyotyping (amplotype) approach which under controlled conditions allows to estimate quantitative changes in DNA content (allelic losses and gains) in tumor cells relative to normal tissue from the same cancer patients [12].

This study aimed to investigate the value of CGH and AP-PCR to detect chromosomal abnormalities in B-CLL and compares their sensitivity with FISH. Both techniques were performed in diagnostic samples from 23 patients with stage A B-CLL, the majority (19 cases) with normal karyotype or not available metaphases. B

\section{Materials and methods}

Twenty-three patients with stage A B-CLL from whom DNA was available at diagnosis were studied. All patients showed lymphocytosis with morphological and immunophenotypical features consistent with B-CLL (CD5+, $\mathrm{CD} 19+, \mathrm{CD} 23+)$. The definition of atypical morphology was based on the FAB classification of CLL. Table 1 summarizes the main disease features. Five patients had disease progression: two died due to the disease-related cause, and three required treatment because of progressive disease.

Cytogenetic studies by conventional methods were carried out in bone marrow cells. Two cultures were established from each sample: one with a B-cell mitogen (pokeweed) and one without mitogens. Clonal abnormalities were described according to the ISCN [13]. Out of 23, 10 showed a normal karyotype, 9 were failures and 4 had an

Table 1

Clinical features of $23 \mathrm{~B}-\mathrm{CLL}$ patients at diagnosis

\begin{tabular}{lc}
\hline Age median (range) & $66(42-87)$ \\
Sex & 18 \\
Male & 5 \\
Female & \\
Stage Binet/Rai & 14 \\
A/0 & 9 \\
A/I & \\
No. of lymphocytes in blood & 20 \\
$\leq 30.000 / \mathrm{mm}^{3}$ & 3 \\
$>30.000 / \mathrm{mm}^{3}$ & \\
Morphology & 21 \\
Typical & 2 \\
Atypical & \\
Histopathological findings & 20 \\
$\quad$ Nondiffuse infiltration of BM & 3 \\
Diffuse infiltration of BM & \\
Clinical course & 18 \\
Stable & 5 \\
Progression/exitus & \\
\hline
\end{tabular}

abnormal karyotype and were used as positive controls (Table 2). The presence of monosomy $\mathrm{Y}$ was not considered as abnormality (cases 5 and 6 ).

CGH was performed according to Kallioniemi et al. [11] with some modifications, as previously described [14].

AP-PCRs were performed in $15 \mu$ l of reaction containing 40,60 , or $80 \mathrm{ng}$ of genomic DNA, $1 \mu \mathrm{M}$ of an arbitrary primer, 1 unit of Taq DNA polymerase (Perkin-Elmer/Cetus), $125 \mu \mathrm{M}$ each of four dNTPs, $10 \mathrm{mM}$ Tris $\mathrm{HCl}(\mathrm{pH}$ 8.3), $1.5 \mu \mathrm{Ci}$ of $\left[\alpha^{-32} \mathrm{P}\right] \mathrm{dCTP}(3000 \mathrm{Ci} / \mathrm{mmol}), 50 \mathrm{mM} \mathrm{KCl}$, $4.5 \mathrm{mM} \mathrm{MgCl}$, and $0.1 \%$ gelatin. Amplification was performed in a PTC 100 thermal cycler (MJ Research) for the first five cycles under low-stringency conditions (at $94^{\circ} \mathrm{C}$ for $30 \mathrm{~s}, 50^{\circ} \mathrm{C}$ for $1 \mathrm{~min}$, and $72^{\circ} \mathrm{C}$ for $1.5 \mathrm{~min}$ ), and then for 25 cycles under high-stringency conditions (at $94^{\circ} \mathrm{C}$ for 15 $\mathrm{s}, 60^{\circ} \mathrm{C}$ for $15 \mathrm{~s}$, and $72^{\circ} \mathrm{C}$ for $1 \mathrm{~min}$ ). PCR products were subjected to electrophoresis in a $5.5 \%$ denaturing polyacrilamide gel. The MCG1 and BLUE arbitrary primers used in this study had been previously described [12].

FISH was performed in 16 cases in which fixed cells were available. The presence of trisomy 12 was assessed by using a probe specific for the centromeric region of chromosome 12, D12Z3. To identify 13q14 deletions we used the LSI D13S25 probe (Vysis, Downers Grove, IL, USA). At least 200 cells were evaluated in each case.

\section{Results and discussion}

The proportion of patients with stage A B-CLL and chromosomal changes increased from $17 \%$ ( $4 / 23$ cases) detected by conventional G-banding to $43 \%$ (10 cases) detected by $\mathrm{CGH}$, and $62 \%$ (15 cases) by AP-PCR. The use of CGH combined with AP-PCR allowed to detect genetic abnormalities in $79 \%$ of cases (15/19) with apparently normal or unsuccessful karyotype (Table 2). As has been reported in previous studies using FISH, in our series losses of $13 \mathrm{q}$ and gains of chromosome 12 were the most frequent changes both by CGH and by AP-PCR [1,4-10]. These results were confirmed by FISH. Besides, these DNA-based techniques allowed to detect several new abnormalities in addition to other recurrent changes.

\subsection{CGH analysis}

CGH showed a number of recurrent unbalances as follows: loss of chromosomal material on 13q (four cases), $6 \mathrm{q}$ (two cases), and 5q (two cases); and gain of chromosomal material on 12q (three cases, two with trisomy 12) and of the chromosomes 17 and 19 (two cases each). Other unbalances of chromosomal regions detected in single cases were: loss of 4q, 7p, 11q, 14q, 15q, 17p, 18q, and Xq, and gain on $1 \mathrm{p}$ and $3 \mathrm{q}$. Detailed data of CGH results compared to cytogenetics and AP-PCR is shown in Table 2. Examples of most significant changes are shown in Fig. 1.

$\mathrm{CGH}$ was more sensitive than G-banding to detect gains of chromosome 12 . Three cases with gains on chromosome 
Table 2

Results of CGH and AP-PCR analysis in 23 patients with B chronic lymphoid leukemia at diagnosis

\begin{tabular}{|c|c|c|c|c|c|}
\hline \multirow[b]{2}{*}{ Case } & \multirow[b]{2}{*}{ G-banding analysis } & \multicolumn{2}{|l|}{$\mathrm{CGH}$} & \multicolumn{2}{|l|}{ AP-PCR } \\
\hline & & Gains & Losses & Gains & Losses \\
\hline 1 & $46, \mathrm{XY}[6] / 48, \mathrm{XY}, \mathrm{t}(2 ; 14)(\mathrm{p} 13 ; \mathrm{q} 32),-10,+3 \operatorname{mar}[20]$ & $12 \mathrm{q} 11 \sim \mathrm{q} 21$ & $17 \mathrm{p} 11 \sim$ pter & Not evaluable & \\
\hline 2 & $47, \mathrm{XX},+12[30]$ & 12 & & $12,13 q 14$ & $\mathrm{~N}$ \\
\hline 3 & 46,XY,dup(13)(q12q13)[32] & 17,19 & $5 \mathrm{q} 15 \sim \mathrm{q} 23,13 \mathrm{q} 21 \sim \mathrm{q} 31$ & $\mathrm{~N}$ & $\mathrm{~N}$ \\
\hline 4 & 46,XY[6]/46,XY,del(6)(q14q21)[16]/45,idem,-Y[24] & & $6 \mathrm{q} 14 \sim \mathrm{q} 23$ & $\mathrm{~N}$ & $\mathrm{~N}$ \\
\hline 5 & $46, X Y / 45, X,-Y$ & 12 & $14 \mathrm{q} 21 \sim \mathrm{q} 31$ & 12 & $\mathrm{~N}$ \\
\hline 6 & $46, X Y / 45, X,-Y$ & $\mathrm{~N}$ & & 12 & $\mathrm{~N}$ \\
\hline 7 & $46, X Y$ & $1 \mathrm{p} 33 \sim \mathrm{p} 36,17,19$ & $\begin{array}{l}4 \mathrm{q} 23 \sim \mathrm{q} 32,6 \mathrm{q} 13 \sim \mathrm{q} 24,13 \mathrm{q} 21 \sim \mathrm{q} 32 \\
18 \mathrm{q} 12 \sim \mathrm{q} 22, \mathrm{Xq} 21\end{array}$ & $9 q 22$ & $\mathrm{~N}$ \\
\hline 8 & $46, \mathrm{XX}$ & $\mathrm{N}$ & & $\mathrm{N}$ & $\mathrm{N}$ \\
\hline 9 & $46, X Y$ & $\mathrm{~N}$ & & $12,13 q 31$ & $\mathrm{~N}$ \\
\hline 10 & $46, X Y$ & $\mathrm{~N}$ & & Not evaluable & \\
\hline 11 & $46, X Y$ & $\mathrm{~N}$ & $\mathrm{~N}$ & $\mathrm{~N}$ & $13 q 14$ \\
\hline 12 & $46, \mathrm{XX}$ & $\mathrm{N}$ & $\mathrm{N}$ & $\mathrm{N}$ & $2,13 \mathrm{q} 14$ \\
\hline 13 & $46, X Y$ & $\mathrm{~N}$ & $\mathrm{~N}$ & $\mathrm{~N}$ & $9 q 22$ \\
\hline 14 & $46, X Y$ & $\mathrm{~N}$ & $\mathrm{~N}$ & $\mathrm{~N}$ & $\mathrm{~N}$ \\
\hline 15 & $46, X Y$ & $\mathrm{~N}$ & $\mathrm{~N}$ & $\mathrm{~N}$ & $\mathrm{~N}$ \\
\hline 16 & Not evaluable & $3 q 26 \sim 29$ & $15 q 26$ & $\mathrm{~N}$ & $\mathrm{~N}$ \\
\hline 17 & Not evaluable & & $5 \mathrm{q} 15 \sim \mathrm{q} 22,7 \mathrm{p} 13 \sim \mathrm{p} 21,13 \mathrm{q} 14 \sim \mathrm{q} 22$ & $8 \mathrm{q} 24$ & $7,13 q 14$ \\
\hline 18 & Not evaluable & & $13 q 14 \sim q 21$ & $\mathrm{~N}$ & $11,13 q 14$ \\
\hline 19 & Not evaluable & & $11 \mathrm{q} 14 \sim \mathrm{q} 23$ & $9 q 22$ & 11 \\
\hline 20 & Not evaluable & $\mathrm{N}$ & & $\mathrm{N}$ & $13 \mathrm{q} 14$ \\
\hline 21 & Not evaluable & $\mathrm{N}$ & & 11 & $\mathrm{~N}$ \\
\hline 22 & Not evaluable & $\mathrm{N}$ & & 12 & $13 q 14$ \\
\hline 23 & Not evaluable & $\mathrm{N}$ & & 12 & $\mathrm{~N}$ \\
\hline
\end{tabular}

$\mathrm{N}$ : Normal

12 were identified by CGH, while only one of them had trisomy 12 by G-banding. In two of these patients gains were complete trisomy 12 . The third patient had a partial trisomy with gain on $12 \mathrm{q} 11 \sim \mathrm{q} 21$ (Fig. 1), a region containing the $M D M$-2 (murine double minute 2) gene, which has been implicated as a relevant target within the trisomy. $M D M-2$ encodes an oncoprotein that operates in an autoregulatory feedback loop with the tumor suppressor protein p53. Amplification of the $M D M-2$ gene leads to over-expression of the protein that inactivates $\mathrm{p} 53$. Over-expression of $M D M-2$ RNA and of several $M D M-2$ proteins have been detected in CLL. Findings in our patient support the importance of this specific region in B-CLL $[1,15,16]$.

Deletions or translocations of chromosome 13 are the most common structural abnormalities in B-CLL. Molecular studies have demonstrated a high incidence of genetic loss, which is frequently homozygous, telomeric to the $R B I$ gene, indicating the site of a potential tumor suppressor gene involved in the pathogenesis of CLL $[17,18]$. In our study, del(13q) was the most common aberration detected by CGH (four cases), although 13q14 band was only involved in two of them. Deletion of chromosome 13 was missed by conventional cytogenetics in all samples.

$\mathrm{CGH}$ detected loss of chromosomal material on $5 \mathrm{q}, 7 \mathrm{p}$, $11 \mathrm{q}, 13 \mathrm{q}$ (two cases), and 15q in 8 cases with normal or unsuccessful karyotype. Two patients had multiple aberrations (cases 5 and 7), one together with +12 and another with del(13q). Furthermore, CGH revealed some additional abnormalities in 2 patients with an abnormal G-banded kary- otype. In case 1 , the chromosomal origin of a marker chromosome could be probably matched with the gain of chromosome $12(12 \mathrm{q} 11 \sim \mathrm{q} 21)$ detected by CGH. In the other (case 3), G-banding detected dup(13q), while CGH also showed an interstitial deletion on $5 \mathrm{q}$ and $13 \mathrm{q}$ and gains of the whole chromosomes 17 and 19. FISH confirmed the del(13q). Although the duplication on chromosome 13 could be material from chromosome 17 or 19 , unresolved chromosomal aberrations, such as marker chromosomes, could not completely explain the differences between CGH and karyotyping. A likely explanation for the discrepancies is that the methods analyze different cell populations [19].

Three previous CGH studies have been published on characterization of the genetic changes in CLL $[6,20,21]$ and only two compared CGH with G-banding results $[6,20]$. Bentz et al. [20] found aberrations in 50\% of normal or not evaluable cases (9/18) whereas Karhu et al. [6] documented concordant results between karyotyping and $\mathrm{CGH}$, with only one abnormal $\mathrm{CGH}$ of 13 patients with normal G-banding. Our study shows that CGH is useful to detect genetic abnormalities in cases in which G-banding did not provide information.

\subsection{AP-PCR analysis}

This is the first study in samples from patients with CLL using AP-PCR. The use of primers MCG1 and BLUE generates a total number of 45 bands with known chromosomal localization, representing the entire human genome with the 

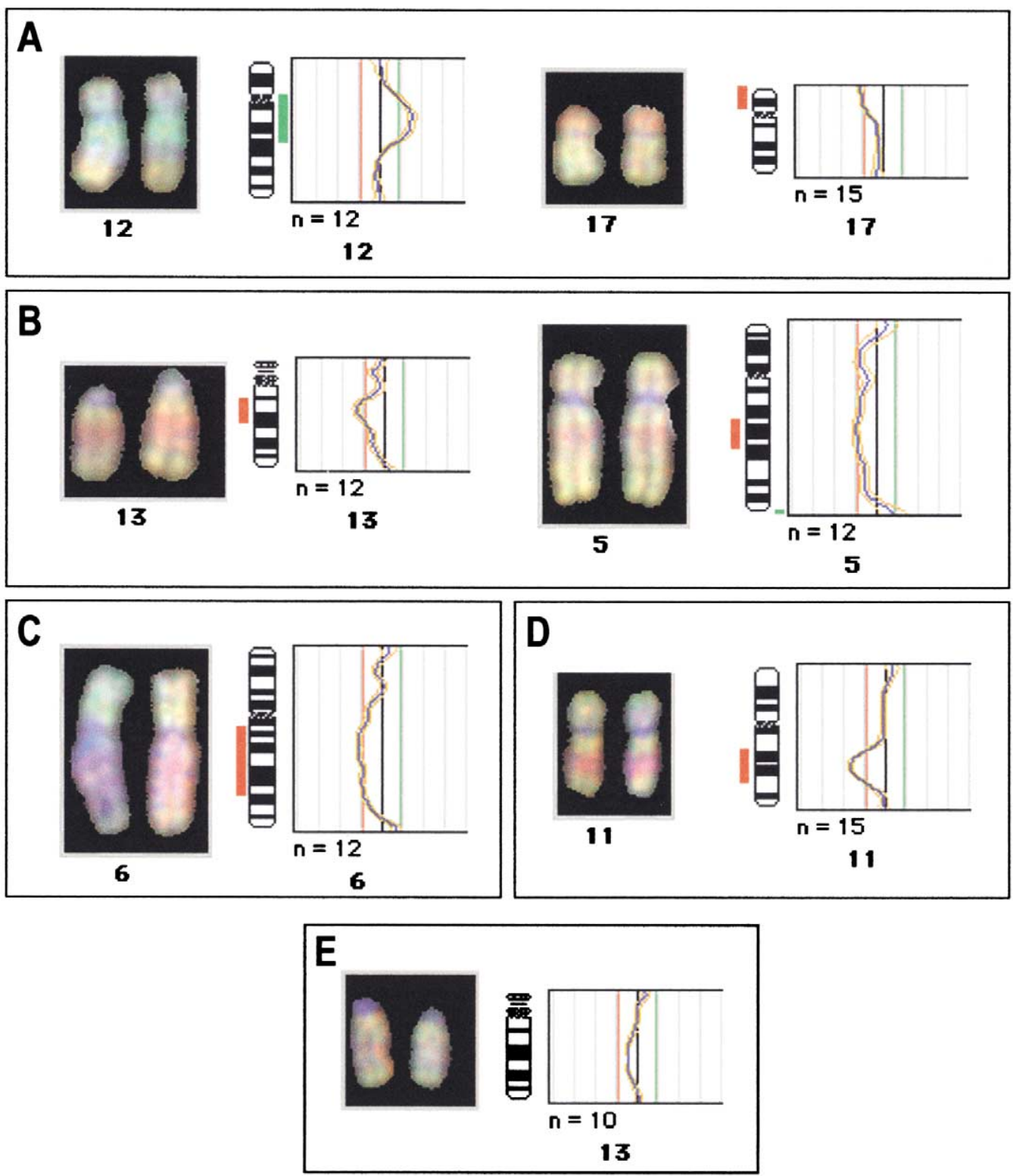

Fig. 1. CGH analysis of B-CLL. Partial karyotypes (left) and corresponding ratio profiles (right) observed in five cases. (A) Case 1 showed an amplified region on chromosome 12 at band $12 \mathrm{q} 11 \sim \mathrm{q} 21$ and loss of $17 \mathrm{p}$. (B) Interstitial deletions in chromosomes 5 and 13 detected in case 17. (C) Loss of chromosomal material on $6 \mathrm{q}$ in case 4. (D) del(11)(q14q22) detected as a single change in case 19. (E) Partial karyotype observed in case 12. Loss of 13q was found to be not significant by the software using the threshold 0.8/1.2.

exception of chromosomes 19, 21 and Y [12]. Table 2 summarizes the genetic alterations detected after the amplotype analysis using these two arbitrary primers. A representative result of these experiments is shown in Fig. 2, which highlights the regions of the amplotype gel containing bands exhibiting consistent changes in these leukemia samples. Determination of losses and gains was carried out by visual inspection and densitometric analyses [12]. The interpretation of chromosome losses and gains was based by comparing leukemic DNA fingerprints with several DNA preparations from normal tissues, and with the previous accumulative DNA data from many normal tissues. Inten- sity changes of some bands such as band I (Fig. 2) were not considered for the analysis because of their polymorphic nature in the human population. However, determination of losses or gains was possible with the fingerprint bands that showed no major fluctuations in their intensities among these normal tissue DNA preparations.

Amplotyping analysis in our series allowed detection of genomic changes in over two-thirds $(15 / 23)$ of patients. The most recurrent alterations were also loss of chromosome 13 sequences in 6 cases (26\%) and gain of chromosome 12 sequences in 6 cases (26\%). MCG1 band $\mathrm{J}$ was responsible for the detection of common losses of chromosome 13 se- 
quences (with the exception of case 1 (Table 2). In contrast, no losses were detected of band $\mathrm{E}$ from the AP-PCR fingerprints with the same MCG1 primer (data not shown). Subchromosomal localization of these two bands using GeneBridge 4 Radiation Hybrid panels indicated that band $\mathrm{E}$ is located at $13 \mathrm{q} 31 \sim \mathrm{q} 32$ and band $\mathrm{J}$ is more centromeric (13q14.1 q14.3). Therefore, band J, but not band $\mathrm{E}$ is located in the region close to the common region of loss identified for CLL, as mentioned. Other recurrent changes were allelic losses of chromosomes 11 (cases 18 and 19), and gains of 9q22 sequences (cases 7 and 19) (Table 2).

AP-PCR was more informative than $\mathrm{CGH}$ for detecting genetic changes in B-CLL (62\% vs $43 \%$ of abnormal cases, respectively) (Table 2 ). This might be because the amplotype is a PCR-based technique that is able to detect alterations in chromosomal regions, which are too small to be detected by $\mathrm{CGH}$. The sensitivity of the $\mathrm{CGH}$ analysis depends on the size of the gain or loss, and on the contamination of the sample with normal cells [22,23]. The resolution for the detection of high-copy number amplifications using $\mathrm{CGH}$ has been defined around $2 \mathrm{Mbp}$. However, only deletions to a size of 10-12 Mbp can be detected based on a diagnostic threshold value of 0.8 , if the vast majority of cells carried the deletion [21]. Interestingly, we detected del(13q) in four patients (cases 11, 12, 20, and 22) using AP-PCR and these results were confirmed by FISH. These patients had also loss on $13 q$ by $\mathrm{CGH}$, although the software did not detect this aberration as significant using the threshold 0.8 / 1.2 (Fig. 1E). The power of AP-PCR is limited because it does not cover the entire genome. This limitation can be in principle ovecome by the use of additional arbitrary primers yielding amplotypes with a higher density of informative chromosomal loci. The discrepancies between the findings in both techniques indicate the need to be used in a complementary way. Although $\mathrm{CGH}$ is less sensitive than AP$\mathrm{PCR}$, the technique is easier and it offers a more complete scope of genetic changes in the whole genome of the tumor.

In conclusion, the application of $\mathrm{CGH}$ and AP-PCR provides new information on gains and losses of chromosomal regions in B-CLL that can be especially useful in cases in which conventional cytogenetics do not provide data on karyotypic abnormalities. In our series, CGH and AP-PCR allowed for the characterization of the abnormalities in $79 \%$ of cases with normal or not evaluable karyotype. Our study using DNA-based techniques confirms that gains of chromosome 12 and loss of $13 \mathrm{q}$, as detected by FISH, are the most common abnormalities, and that in several cases these aberrations are not the sole abnormality in the karyotype.

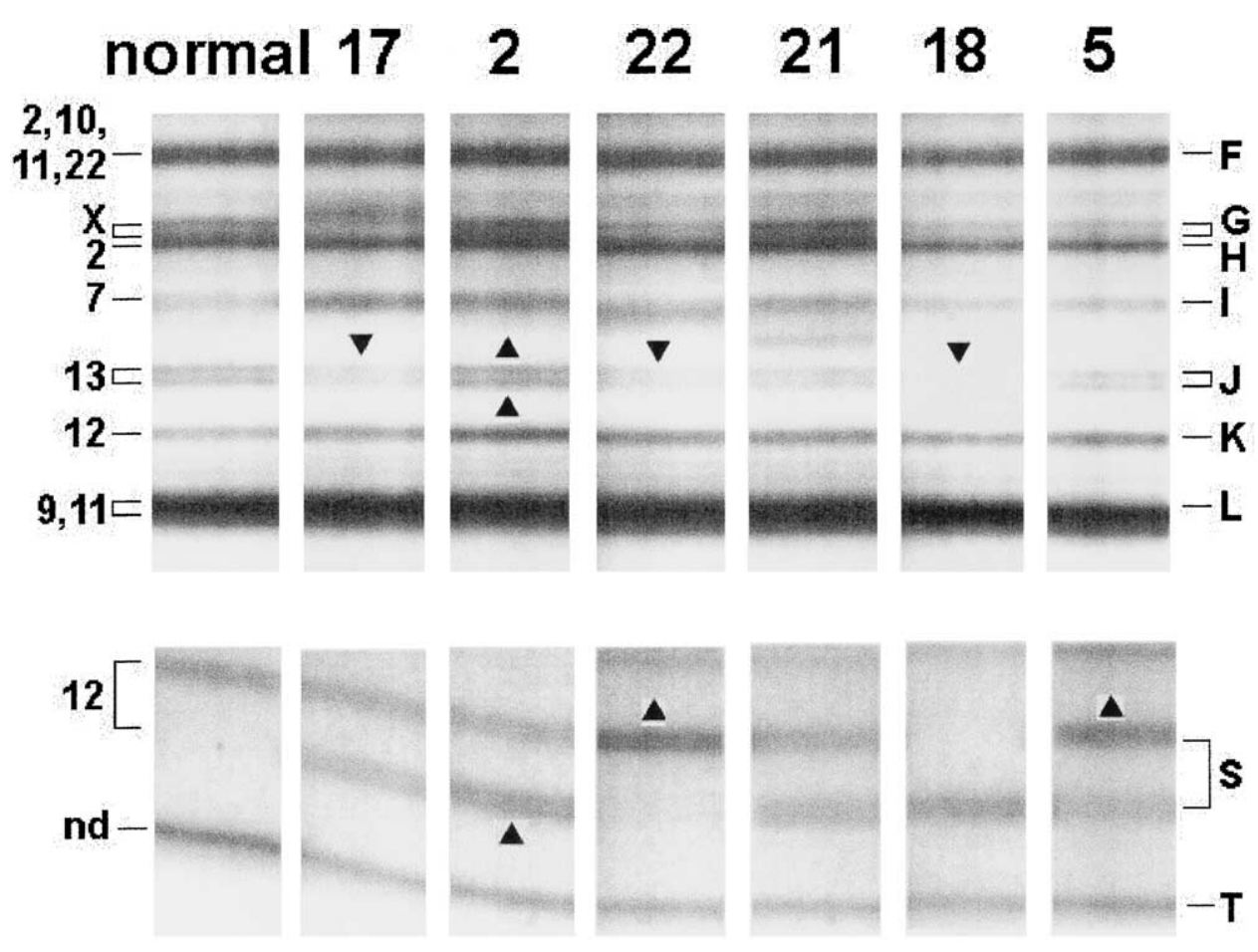

Fig. 2. AP-PCR DNA fingerprinting analysis of B-CLL. Patient identification number is indicated at the top. DNA from normal colon tissue was used as a diploid control (see text). Two lanes were loaded from each case corresponding to AP-PCR reactions with 40 and 60 ng of genomic DNA. Numbers at the left indicate the chromosomal origin of the bands named by letters at the right. Changes in the intensity of band $\mathrm{G}$ indicate genetic dosage of chromosome $\mathrm{X}$, which identifies the gender of the patients. BAND I from chromosome 7 is polymorphic in the human population, affecting to the primer annealing site, and, therefore, in the absence of matching normal tissue, changes of this band cannot be considered for karyotyping purposes. Cases 17,18 , and 22 show loss of band $\mathrm{J}$ at $13 \mathrm{q} 14$. Band $\mathrm{S}$ on chromosome 12 is represented by two polymorphic alleles with different length. Cases 2 and 5 are heterozygous for this polymorphism and show gain of the lower allele in case 2 and gain of the upper allele in case 5 . These gains can be detected also in band $\mathrm{K}$ from the Blue primer derived from chromosome 12 . 
Both CGH and AP-PCR might also be useful in the detection of complex karyotypes, which seem to have a clinical impact [4], and could contribute to the future discovery of more specific genetic markers for B-CLL. Other studies in a larger number of patients are required to determine recurrent abnormalities with prognostic significance.

\section{References}

[1] Caligaris-Cappio F, Hamblin TJ. B-cell chronic lymphocytic leukemia: a bird of a different feather. J Clin Oncol 1999;17:399-408.

[2] Rozman C, Montserrat E. Chronic lymphocytic leukemia. N Engl J Med 1995;333:1052-7.

[3] Oscier DG, Matutes E, Copplestone A, Pickering RM, Chapman R, Gillingham R, Catovsky D, Hamblin TJ. Atypical lymphocyte morphology: an adverse prognostic factor for disease progression in stage A CLL independent of trisomy 12. Br J Haematol 1997;98:934-9.

[4] Juliusson G, Merup M. Cytogenetics in chronic lymphocytic leukemia. Semin Oncol 1998;25:19-26.

[5] Matutes E, Oscier D, Garcia-Marco J, Ellis J, Copplestone A, Gillingham R, Hamblin T, Lens D, Swansbury GJ, Catovsky D. Trisomy 12 defines a group of CLL with atypical morphology: correlation between cytogenetic, clinical and laboratory features in 544 patients. $\mathrm{Br}$ J Haematol 1996;92:382-8.

[6] Karhu R, Knuutila S, Kallioniemi OP, Siltonen S, Aine R, Vilpo L, Vilpo J. Frequent loss of the 11q14-24 region in chronic lymphocytic leukemia: a study by comparative genomic hybridization. Tampere CLL Group. Genes Chromosom Cancer 1997;19:286-90.

[7] Dohner H, Stilgenbauer S, James MR, Benner A, Weilguni T, Bentz M, Fischer K, Hunstein W, Lichter P. 11q deletions identify a new subset of B-cell chronic lymphocytic leukemia characterized by extensive nodal involvement and inferior prognosis. Blood 1997;89: 2516-22.

[8] Neilson JR, Auer R, White D, Bienz N, Waters JJ, Whittaker JA, Milligan DW, Fegan CD. Deletions at 11q identify a subset of patients with typical CLL who show consistent disease progression and reduced survival. Leukemia 1997;11:1929-32.

[9] Starostik P, O'Brien S, Chung CY, Haidar M, Manshouri T, Kantarjian $\mathrm{H}$, Freireich E, Keating M, Albitar M. The prognostic significance of 13q14 deletions in chronic lymphocytic leukemia. Leuk Res 1999;23:795-801.

[10] Dohner H, Stilgenbauer S, Benner A, Leupolt E, Krober A, Bullinger L, Dohner K, Bentz M, Lichter P. Genomic aberrations and survival in chronic lymphocytic leukemia. N Engl J Med 2000;343:1910-16.

[11] Kallioniemi OP, Kallioniemi A, Piper J, Isola J, Waldman FM, Gray JW, Pinkel D. Optimizing comparative genomic hybridization for analysis of DNA sequence copy number changes in solid tumors. Genes Chromosom Cancer 1994;10:231-43.

[12] Malkhosyan S, Yasuda J, Soto JL, Sekiya T, Yokota J, Perucho M.
Molecular karyotype (amplotype) of metastatic colorectal cancer by unbiased arbitrarily primed PCR DNA fingerprinting. Proc Natl Acad Sci USA 1998;95:10170-5.

[13] ISCN. An international system for human cytogenetic nomenclature. F Mitelman, editor. Basel: S. Karger, 1995.

[14] Cigudosa JC, Rao PH, Calasanz MJ, Odero MD, Michaeli J, Jhanwar SC, Chaganti RS. Characterization of nonrandom chromosomal gains and losses in multiple myeloma by comparative genomic hybridization. Blood 1998;91:3007-10.

[15] Merup M, Juliusson G, Wu X, Jansson M, Stellan B, Rasool O, Roijer E, Stenman G, Gahrton G, Einhorn S. Amplification of multiple regions of chromosome 12, including 12q13-15, in chronic lymphocytic leukaemia. Eur J Haematol 1997;58:174-80.

[16] Dierlamm J, Wlodarska I, Michaux L, Vermeesch JR, Meeus P, Stul M, Criel A, Verhoef G, Thomas J, Delannoy A, Louwagie A, Cassiman JJ, Mecucci C, Hagemeijer A, Van den Berghe H. FISH identifies different types of duplications with $12 \mathrm{q} 13-15$ as the commonly involved segment in B-cell lymphoproliferative malignancies characterized by partial trisomy 12. Genes Chromosom Cancer 1997;20: 155-66.

[17] Liu Y, Corcoran M, Rasool O, Ivanova G, Ibbotson R, Grander D, Iyengar A, Baranova A, Kashuba V, Merup M, Wu X, Gardiner A, Mullenbach R, Poltaraus A, Hultstrom AL, Juliusson G, Chapman R, Tiller M, Cotter F, Gahrton G, Yankovsky N, Zabarovsky E, Einhorn $\mathrm{S}$, Oscier D. Cloning of two candidate tumor suppressor genes within a $10 \mathrm{~kb}$ region on chromosome $13 \mathrm{q} 14$, frequently deleted in chronic lymphocytic leukemia. Oncogene 1997;5:2463-73.

[18] Kalachikov S, Migliazza A, Cayanis E, Fracchiolla NS, Bonaldo MF, Lawton L, Jelenc P, Ye X, Qu X, Chien M, Hauptschein R, Gaidano G, Vitolo U, Saglio G, Resegotti L, Brodjansky V, Yankovsky N, Zhang P, Soares MB, Russo J, Edelman IS, Efstratiadis A, Dalla-Favera R, Fischer SG. Cloning and gene mapping of the chromosome $13 q 14$ region deleted in chronic lymphocytic leukemia. Genomics 1997;42:369-77.

[19] Persso K, Pandis N, Mertens F, Borg A, Baldetorp B, Killander D, Isola J. Chromosomal aberrations in breast cancer: a comparison between cytogenetics and comparative genomic hybridization. Genes Chromosom Cancer 1999;25:115-22.

[20] Bentz M, Huck K, du Manoir S, Joos S, Werner CA, Fischer K, Dohner H, Lichter P. Comparative genomic hybridization in chronic B-cell leukemias shows a high incidence of chromosomal gains and losses. Blood 1995;85:3610-18.

[21] O'Connor SJ, Su'ut L, Morgan GJ, Jack AS. The relationship between typical and atypical B-cell chronic lymphocytic leukemia. A comparative genomic hybridization-based study. Am J Clin Pathol 2000; $114: 448-58$.

[22] Bentz M, Plesch A, Stilgenbauer S, Dohner H, Lichter P. Minimal sizes of deletions detected by comparative genomic hybridization. Genes Chromosom Cancer 1998;21:172-5.

[23] Bentz M, Stilgenbauer S, Lichter P, Dohner H. Interphase FISH in chronic lymphoproliferative disorders and comparative genomic hybridisation in the study of lymphomas. Haematologica 1999;84:102-6. 